\title{
Evisceration of umbilical content with extensive adhesion: A surgical approach
}

\author{
Pravin Mishra $^{1}$ (D) | Vivek Kumar Yadav ${ }^{1}$ (D) | Moinul Hasan ${ }^{2}$ (D)
}

\author{
${ }^{1}$ Faculty of Veterinary Science, Bangladesh \\ Agricultural University, Mymensingh, \\ Bangladesh \\ ${ }^{2}$ Department of Surgery and Obstetrics, \\ Bangladesh Agricultural University, \\ Mymensingh, Mymensingh, Bangladesh \\ Correspondence \\ Moinul Hasan, Department of Surgery \\ and Obstetrics, Bangladesh Agricultural \\ University, Mymensingh-2202, Bangladesh. \\ Email: moinul.vet@bau.edu.bd
}

\begin{abstract}
With timely recognition and surgical intervention along with administration of an antibiotic, antihistaminic, and anti-inflammatory drugs, evisceration of umbilical content with extensive adhesion can be treated, and the outcome is also good.
\end{abstract}

\section{K E Y W O R D S}

electrocauterization, evisceration, umbilical hernia

\section{1 | INTRODUCTION}

Umbilical hernia is occasionally seen with different levels of complexity in animals. However, eviscerated umbilical hernia with extensive adhesion in a bovine calf is not much common. With timely recognition, surgical intervention, and administration of an antibiotic, antihistaminic, and anti-inflammatory drugs, the outcome is generally good.

Twenty days old indigenous male bovine calf having body weight $40 \mathrm{~kg}$ presented with the complaint of swollen umbilical contents at Veterinary Teaching Hospital, Bangladesh Agricultural University, Mymensingh, Bangladesh. Physical examination confirms the case is an evisceration of umbilical content with extensive adhesion which is not much common in the bovine calf (Figure 1). All the other clinical parameters were found normal, which confirmed the calf was free from another infectious disease.

Umbilical herniorrhaphy was done where electrocauterizer was used to incise the eviscerated tissue, which contains the part of the small intestine and also to minimize the bleedings. All the contents were put back in the abdominal cavity. Finally, the ring, muscle, and skin were sutured separately (layer by layer) with polyglactin 910 (No. 1-0), catgut (No. 1-0), and nylon (No. 1) (Figure 2), respectively. Along with the surgical process, administration of antibiotic, antihistamine, and anti-inflammatory medication was done, and proper hygienic management was suggested. Now the calf is healthy and doing well.

The evisceration of the intestine may occur spontaneously after gradual worsening of the hernia and thinning of the wall,

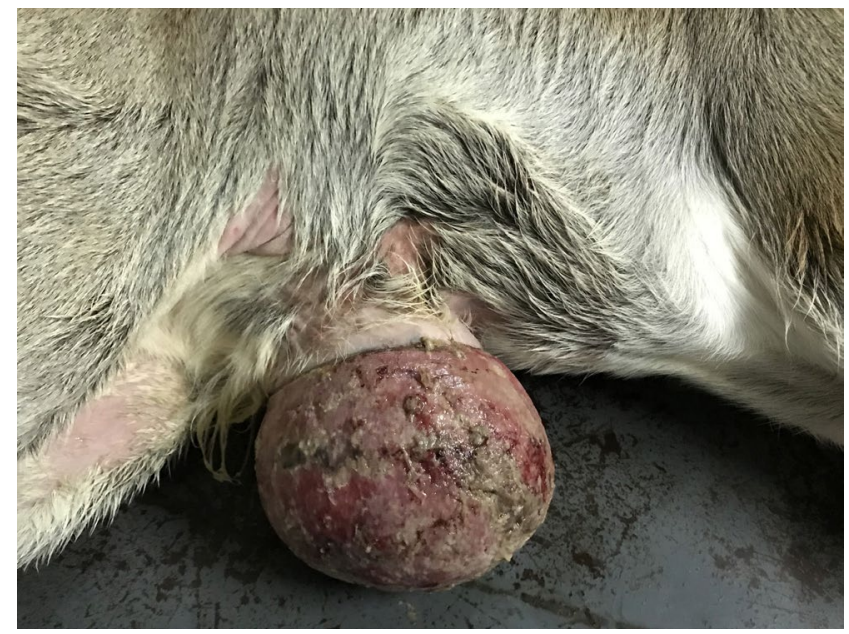

F IG URE 1 Evisceration of umbilical content with extensive adhesion in bovine calf

This is an open access article under the terms of the Creative Commons Attribution License, which permits use, distribution and reproduction in any medium, provided the original 


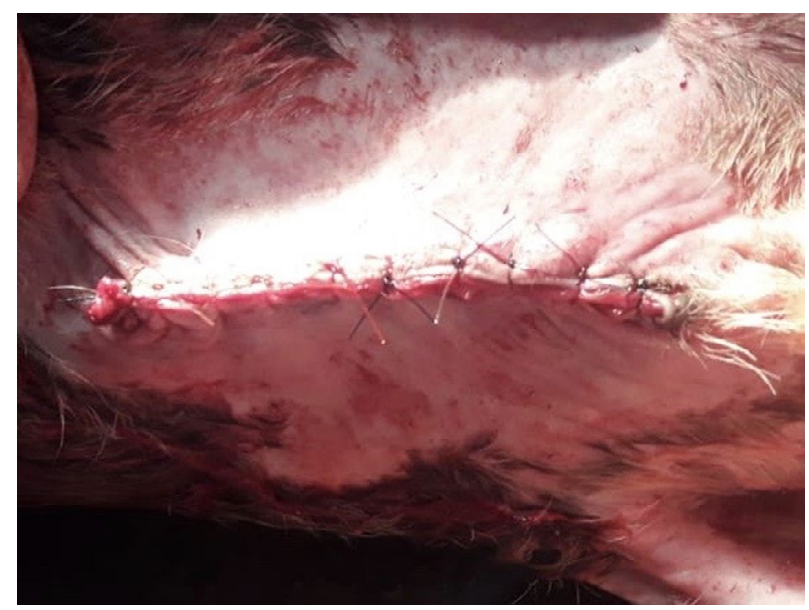

F I G U RE 2 Simple interrupted suture on skin using nylon

or it may be abruptly caused by trauma or sudden straining. ${ }^{1}$ With the timely surgical intervention and proper hygienic management of umbilical hernia, the outcome is generally good, otherwise recurrence or secondary infections may be seen as the chance of bacterial infection is high in male calves because of their anatomical structures. ${ }^{2,3}$

\section{ACKNOWLEDGMENTS}

We like to thank the supporting staff of Veterinary Teaching Hospital of Bangladesh Agricultural University, Mymensingh, for their technical helps during surgical procedures.

\section{CONFLICT OF INTEREST}

The authors declare that there is no conflict of interest regarding the publication of this manuscript.

\section{AUTHOR CONTRIBUTIONS}

PM and MH: diagnosed the case and performed the surgery. PM and VKY: wrote the manuscript. All authors: revised the manuscript critically and approved the final version to be published.

\section{ETHICAL APPROVAL}

Ethics approval was not required for this study.

\section{ORCID}

Pravin Mishra (D) https://orcid.org/0000-0002-8315-0463

Vivek Kumar Yadav (D) https://orcid.

org/0000-0001-8809-757X

Moinul Hasan (D) https://orcid.org/0000-0001-9994-9555

\section{REFERENCES}

1. Mishra P, Mahmud MM, Yadav VK, Hasan M. Umbilical hernia with extensive adhesion and evisceration in a bovine calf. Iran J Vet Surg. 2020;15(1):92-95.

2. Jaman MM, Mishra P, Rahman M, Alam MM. Clinical and laboratory investigation on the recurrence of the umbilical hernia after herniorrhaphy in bovine calves. J Bangladesh Agril Univ. 2018;16(3):464-470.

3. Rassel MG, Mishra P, Rahman M, Alam MM. Exploring bacterial pathogens and risk factors associated with the occurrence of navel ill in calves. J Ist Vet Sci. 2020;4(2):37-42.

How to cite this article: Mishra P, Yadav VK, Hasan M. Evisceration of umbilical content with extensive adhesion: A surgical approach. Clin Case Rep. 2020;8:3568-3569. https://doi.org/10.1002/ccr3.3217 


\section{University Library}

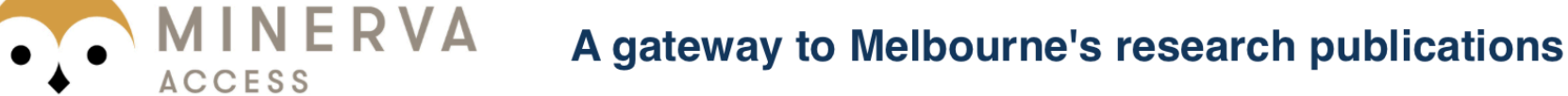

Minerva Access is the Institutional Repository of The University of Melbourne

Author/s:

Mishra, P;Yadav, VK;Hasan, M

Title:

Evisceration of umbilical content with extensive adhesion: A surgical approach

Date:

2020-08-09

Citation:

Mishra, P., Yadav, V. K. \& Hasan, M. (2020). Evisceration of umbilical content with extensive adhesion: A surgical approach. CLINICAL CASE REPORTS, 8 (12), pp.3568-3569. https:// doi.org/10.1002/ccr3.3217.

Persistent Link:

http://hdl.handle.net/11343/296332

License:

CC BY 